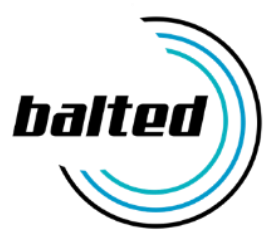

Vatansever, S. (2021). Luan Starova'nın Keçiler Dönemi Romanına Bir Bakış. Balkanlarda Türk Dili ve Edebiyatı Araştırmaları, 3(1), 107-125. DOI: 10.47139/balted.808765

\title{
Luan Starova'nın Keçiler Dönemi Romanına Bir Bakış
} A Review of Luan Starova's Novel The Time of the Goats

\section{Sema VATANSEVER ${ }^{*}$}

\begin{abstract}
Öz
Keçiler Dönemi; farklı dinden, ideolojiden, milletten insanlara ve silinip giden imparatorluklara ev sahipliği yapmış Balkanlar'ın adeta modern destanıdır. Roman, daha isminden itibaren alışılagelmiş tarih/devir anlayışına başkaldırır. Üsküp şehri eserde "labirent mekân"a dönüşürken, romanın temel izleklerinden olan "göç"ün trajik boyutu "nehir/ su" imgesi üzerinden anlatılır. Ölüm, arayış, yolculuk ve yeniden doğuş arketiplerini barındırması yönüyle "arketipçi eleştiri" (archetypal criticism) bağlamında incelenmeye müsait olan roman; dilin yersiz yurtsuzlaşması, ötekilik ve azınlık vurgusu, bireyin zorunlu olarak bilhassa dilde siyasallaşması, politik ve kolektif söylemi taşıması bakımından da "minör edebiyat"a eklemlenir. Kuzey Makedonya'da yaşayan Arnavut asıllı Starova; romanlarını Makedonca başta olmak üzere, Fransızca ve Arnavutça yazmak suretiyle daha ziyade majör dilde edebî ürün vermektedir. Romanda, gönderge (référence), parodi (parody), yeniden yazma (réécriture) ve ekfrasis (ekphrasis) boyutunda "metinlerarasılık/göstergelerarasılık" tekniklerinden faydalanılmıştır. Bu çalışma Starova'nın derin yapıda yoğun imgesellik barındıran, entelektüel altyapısı diyalog kurduğu diğer yazarlar, şairler ve ressamlar ile zenginleştirilmiş Keçiler Dönemi romanının bahsi geçen kuramlar çerçevesinde, genel hatları itibariyle incelemesini içermektedir.
\end{abstract}

Anahtar Kelimeler: Keçiler Dönemi, Minör Edebiyat, Arketipçi Eleştiri, Metinlerarasılık, Ekfrasis.

\begin{abstract}
The Time of the Goats is the modern epic of the Balkans, which has hosted people from different religions, ideologies, nations and empire. The novel, starting from its name, revolts against conventional understanding of history/era. When Skopje turns into a "labyrinth city" in the work, the tragic aspect of the "migration" is told through the image of the river. The Time of the Goats is suitable for analysing in the context of "archetypal criticism" by containing archetypes of death, seeking, journey and rebirth. The book is also articulated to "minor literature" in terms of alterity, minority emphasis, linking the individual to politics and carrying the collective rhetoric. Albanian writer Starova, who lives in North Macedonia, wrote his novels mainly in Macedonian, French
\end{abstract}

\footnotetext{
* Yüksek Lisans Öğrencisi, Marmara Üniversitesi, Türkiyat Araştırmaları Enstitüsü, Yeni Türk Edebiyatı Bilim Dalı, semavatansever96@gmail.com, ORCID: 0000-0003-1074-5201
} 
and Albanian. He mostly produces literary works in major languages. Intertextuality/ intersemiotic techniques (référence, parody, réécriture, ekphrasis etc.) are used in the novel. This study includes an overview of the novel The Time of the Goats in the context of mentioned theories.

Keywords: The Time of the Goats, Minor Literature, Archetypal Criticism, Intertextuality, Ekphrasis.

\section{Giriş}

Keçiler Dönemi (Starova, 2000b) göçlere, savaşlara, parçalanmalara, devrimlere, silinip giden imparatorluklara ve yeniden çizilen sınırlara sahne olmuş; farklı dinden, mezhepten ve milletten insanlara ev sahipliği yapmış Balkanlar'ın modern destanıdır. Tarihi kazananlar yazsa da son sözü söyleyen her hâlükârda; o devri bünyesinde taşıyan şiirler, romanlar, öyküler, resimler ve mimari yapılardır. Üstelik geçmişten bugüne, sanatın "yalan"ı tarihin yavan gerçeğinden daha çok ilgi görmüştür. İşte bu yüzden roman, daha isminden itibaren alışılagelmiş tarih/devir anlayışına başkaldırır: Mevzubahis olan ne Romalılar dönemidir ne Bizanslılar ne de Osmanlılar. Devir realitede, yani tarihin adlandırması bakımından Soğuk Savaş’ı içermektedir ve ülkenin - Yugoslavya Sosyalist Federal Cumhuriyeti- önderi Tito'dur. Ancak yazar, tarihin matematiksel bir kurgudan ibaret olduğunu düşünürcesine bu adlandırmaları yadsır. Okuru hafızanın derin sularında yüzdüren romanın kahramanı ${ }^{1}$; beyaz karşı-devrimin önderi, soylu vahşi diyebileceğimiz Başkeçi Çobanı Çanga ${ }^{2}$ iken, bitmek bilmeyen kanlı kıtık dönemine sütüyle can veren de sadık keçilerdir. Dönem, "Keçiler Dönemi”dir.

Yazar, anlatımındaki ironi sayesinde Kül Kalesi (Starova, 2008) romanından farklı olarak, tarihsel hakikatlerin üzerini bireysel tarih, kimlik krizi, metinlerarası ilişkiler ve sinematografik imgelerle örtmüş; tarihi bir arka fon olarak kullanmıştır. Balkanlar'daki komünist uygulamalar ve iç savaşlar hakkında pek bilgisi olmayan bir okur, romandaki siyasi uzantıları rahatlıkla metaforik boyutta alımlayabilir.

Bu çalışmada Luan Starova'nın Keçiler Dönemi romanına odaklanma sebebimiz; Meşa Selimoviç, İvo Andriç gibi Balkan edebiyatı yazarlarının romanları hakkında Türkiye'de pek çok akademik ve popüler yayın yapılırken 1997 yılında

\footnotetext{
${ }^{1}$ Burada "kahraman" ifadesini, destanlara telmihen parodi maksadıyla kullandığımızı belirtmek isteriz. Zira modernist romanda kahramanlar değil, roman kişileri yer alır. Mitolojide yalnız bir Achilles ve yine yalnız bir Paris vardır. Onlar, tüm özellikleriyle yegânedir. Oysa Çanga, tasvir edilen "kahramansı" niteliklerinin yanında bütünüyle dünyalıdır. Onun efsaneleşen varlığı, modernist romanın destan kahramanlarını selamlamasıdır.

${ }^{2}$ Romanda yalnızca Çanga'nın adı belirtilmiştir: "Melko Melovski". Çanga dışındaki roman kişileri Blanchette, Stalinette ve Laideronne isimleriyle sembolik anlam yüklenen üç keçi hariç- isimsizdir. Bu tutum da modernist romanın uzantılarındandır. Kimlik bunalımıyla ilintili olarak kimliğin bir parçası olan isim dahi buharlaşır. Roman kişisi “herkes"leşir. En bilindik uygulayıcısı Kafka'dır. Kafka'nın protagonistleri de yalnızca isminin baş harfiyle anılır.
} 
Fransa' da "En İyi Roman" ödülüne layık görülen Keçiler Dönemi ve Starova'nın diğer eserleri hakkındaki çalışmaların sınırlı sayıda kalmasıdır. Ertuğrul Karakuş ve Rabia Uçkun'un “Balkan Halklarının Kimlik Belgeleri: "Kül Kalesi (Siciller)” Romanı Üzerine Bir Değerlendirme" (2012, s. 231 vd.), Hürriyet Gazetesi'nde isimsiz olarak yayınlanan "Ata'nın Gizli Hayatı” adlı yazarın Kül Kalesi romanı hakkındaki röportaj (2008, 19 Eylül), Ziya Gürel'in Aydınlık Gazetesi Kitap Eki'nde "Yitik Zamana İz Düşen Roman" başlığıyla yayınlanan Babamın Kitapları romanına dair tanıtım yazısı (2013, 5 Temmuz), Neslihan Demirci'nin BSV Bülten'de yayınlanan "Balkanların Romanında Tarihin İzini Sürmek" adlı değerlendirmesi (2009, 5 Mayıs)... bu yayınlar arasında zikredilebilir. Ayrıca çalışmamızla ilgili birincil kaynak özelliği taşımasa da Seyhan Murtezan Ibrahimi'nin Starova romanlarında Osmanlı sicillerinin etkisine odaklanan "The Place And Significance Of Ottoman Judicial Records In The Novels Of Luan Starova As Representative Of Macedoninan Literature" (2018, s. 53-58) adlı makalesi yine akademik çalışmalar bağlamında anılmalıdır.

Kuramsal çerçevede ele alınan Keçiler Dönemi romanı hakkındaki incelememizin, kaynakların sınırlılığı nedeniyle barındırabileceği noksanlıklara rağmen alandaki boşluğu doldurması açısından mühim bir merhale olduğu görüşündeyiz. Bu makale, Starova eserleri hakkında halihazırda yürütmekte olduğumuz diğer çalışmaların genelleyici ilk ayağını oluşturması cihetiyle de ayrı bir önem taşımaktadır.

\section{Labirent Mekâna Dönüşen ‘Kayıp Şehir’: Üsküp}

Kanlı geçmişe inat, göçmen kuşların yeni hayatlara yol almak için tutamak bellediği, uzakları terennüm eden Vardar Nehri ile; büyük depremlerin yıkıcılığına rağmen ayakta kalmak için direnen mağrur kalesi ile Üsküp romanda labirent mekâna dönüşür. Başkent, keçilerin ve çobanların istilâsına uğrar. Kulağa fantastik gelen ve ana aksiyonu oluşturan "beyaz karşı-devrim” geçmeden önce, romanın başında ayrıntıyla tasvir edilmiş şehrin o zamanki görünümüne bir göz atalım:

"Kent halkının gözbebeği Şato, kente yeni gelmiş bizlere boşlukta asılı bir balkon gibi görünüyordu. Üzerinde kalenin yükseldiği tepeciğin eteklerine erişmek isteyen birinin önce Tahtaköprü'yü geçmesi gerekiyordu. Baştan sona tahtadan yapılmış bu güzel köprüyü geçer geçmez hakiki bir saray; ön cephesinde, görünümleri alabildiğine değişik kabartma suretler ve masklarla çevrelenmiş, adeta insan boyutunda bir dizi heykelin, heykel-sütunların yer aldığı bembeyaz bir saray gözler önüne seriliyordu.

Neoklasik tarzda burada inşa edilmiş ama Viyana'dan, Roma'dan ya da Paris'ten dosdoğru Balkanlar'ın merkezine aktarılmış gibi bir izlenim bırakan bu 
saygın yapı Tiyatro idi. (...) Balkanlar'da kurulmuş olan bütün imparatorlukların başlıca dayanak noktası olarak bilinen muazzam kale kentin görünümünde hiç değişmeyecek özellikleri oluşturuyordu." (Starova, 2000b, s. 7-8)

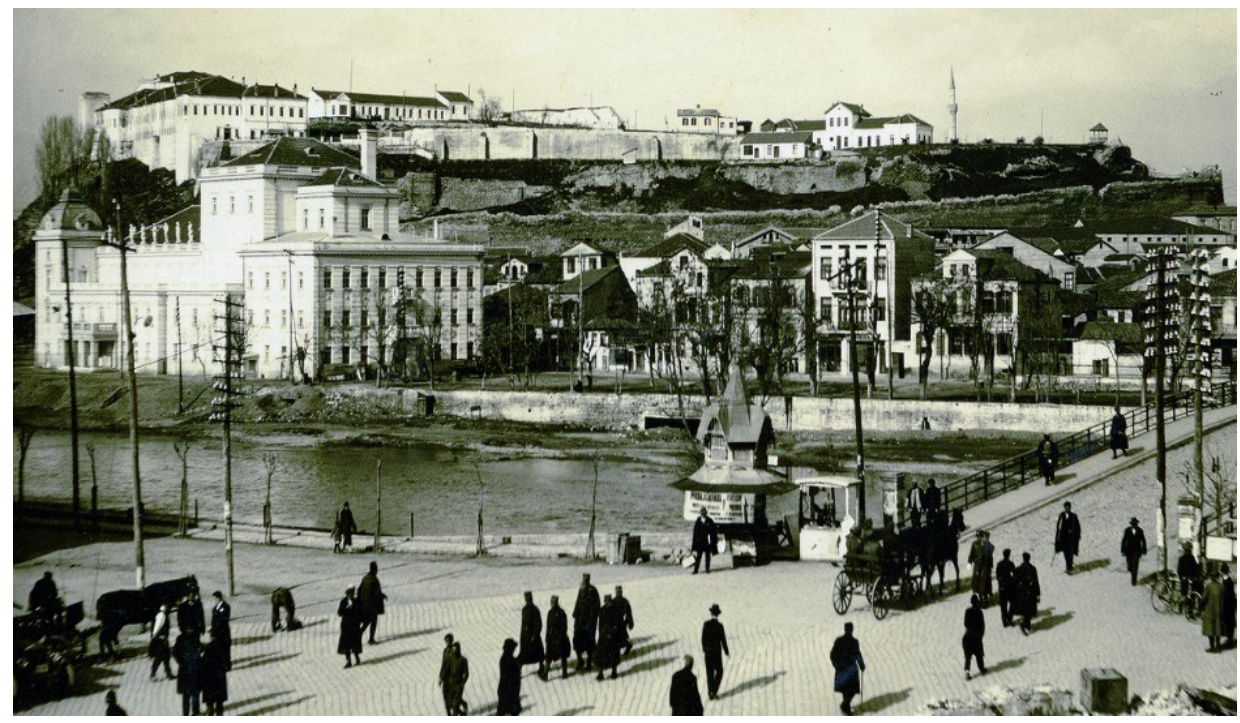

Şekil 1: Üzerinde kalenin yükseldiği tepe ve 1963 depreminden önceki Ulusal Tiyatro binası (DARM)

\footnotetext{
${ }^{3}$ Millî Kurum Türk Tiyatrosu'nun web sitesinde yer alan tarihçeye göre; imparatorluğun ikinci büyük şehri Selânik'te tiyatro alanında kaydedilen gelişmeler Üsküp ve Manastır'da da etkisini göstermeye başlamış, seyyar tiyatro gruplarının sayısı o denli artmıştır ki başkent Üsküp'te bir tiyatro binasının inşası ihtiyaç hâline gelmiştir. Mahmut Şevket Paşa'nın Üsküp valiliği görevine atanmasıyla binanın inşası fikri gerçekleşmiştir. Mevzubahis olan tiyatro, ilk çalışmalarına 1906 yılında başlamıştır. Üsküplülerin hatırında Türk Tiyatrosu olarak kalan bu yapı, Üsküp’te inşa edilen ilk tiyatro binasını teşkil eder. İlk Üsküp tiyatro binası Makedon Halk Tiyatrosu'nun eski yerinde kurulmuş ve abidevî bir yapı olarak işlev görmüştür. Detaylı bilgi için bk. (MK Türk Tiyatrosu, 2020). Ayrıca, Gönül Bektaş'ın da "Üsküp’te Osmanlı Tiyatrosu” adlı incelemesinde aktardığı bilgilere göre, Ago Paşa Köprüsü'nün (Üsküp ağzıyla "Tahta Köprü”) hemen yanındaki tiyatro 1912 yılında, Osmanlı'nın ülkeyi terk etmek zorunda kalışından sonra, 3 Şubat 1914'teki yangına kadar yeni gelen Sırp yöneticiler tarafından çalıştırılır. Yangında tümüyle yok olan tiyatronun yerine, Sırp yönetimince 1927 yılında aynı yerde ve aynı büyüklükte Neo-Klasik biçemde yeni bir bina inşa edilir. (bk. görseldeki bina.) Bu yapı 1963 Üsküp depremine değin kullanılır. Depremde büyük hasar gören tiyatro, 2013 yılında aynı biçemde yeniden tasarlanarak inşa edilir. Bugün de hâlen kullanılmaktadır; bk. (Bektaş, 2015).
} 
Tıpkı Joyce'un Ulysses'inde Dublin'in, Tanpınar'ın Huzur'unda İstanbul'un romancı muhayyilesindeki haritasının çıkarılabileceği gibi; Starova'nın Keçiler Dönemi romanındaki betimlemelerinden de Üsküp'ün haritası çıkarılabilir. Eserin yalnız birinci bölümünde değil, bütününde tasvirler hayli yekûn tutmakta, başkent neredeyse bir karaktere dönüşmektedir. "Köklerinden kopma" ve "hiçbir yerin yerlisi" olamama trajedisiyle paralel okunduğunda, mekân unsurunun niçin kendini kuvvetle hissettirdiği başka türlü idrak edilecektir. O dönemin Üsküp’ü - İkinci Dünya Savaşı'ndan henüz çıkıldığını, romanın başında Stalin ile Tito'nun arasının iyi olduğunu fakat sonuna doğru ikili arasındaki ayrılığın patlak verdiğini zamana dair ipuçları olarak göz önünde bulundurursak; 1947-1955 yılları arasındaki Üsküp'ün anlatıldığı söylenebilir. - Sefarad Yahudilerini, Ermenileri, Ekim Devrimi'nden canını kurtarmış Rus aileleri, Türk aileleri, Yunanistan Makedonya'sından gelen aileleri ve Arnavutları barındırdığı için Balkanlar'daki dinî ve etnik kaosun panoramasını sunmaktadır (Starova, 2000b). Zaten mikro düzeyde Üsküp'ün, büyük çerçevede ise Balkanlar'ın tarihi savaşlar, yıkıntılar ve göçlerle birlikte yürür.

Kente inen keçilerin muştuladığı "yaşam" sayesinde, tarihte ilk defa olarak tüm ayrımlar silinmiş, köylüler/çobanlar ile kentliler romanda anlatıldığı denli yakınlaşmışırı. Fransız Devrimi ve Ekim Devrimi'nden aparılan "sınıf mücadelesi" bağlamında düşünüldügünde, yeni rejimin çobanları dağlardan inmeye çağırma amacı onları sosyalist devrimi gerçekleştirecek "işçi sınıfı"na dönüştürmektir. Fakat Partililer'in hesaba katmadığı bir şey vardır; çobanlar kutsal saydıkları, çocukları olarak gördükleri keçileriyle birlikte gelmiştir. Meydanı sürreal şekilde binlerce keçi ve çoban doldurmuştur. Parti ideologlarının dilince söylersek; "kent 'keçilerin istilasına' uğramıştır." (Starova, 2000b, s. 13) Çobanların Parti il Komitesi Sekreteri'ne ve Belediye Başkanı'na karşı ilk zaferi; Başkeçi Çobanı Çanga'nın keçilere yer olmadığını, onları kentte barındırmanın mümkün olamayacağını söyleyen Parti Sekreteri'ne başkaldırısının sonuç vermesi olmuştur. Çobanlar beraberinde getirdikleri keçilerini bırakmamakta direnmiş, tek odalı konutlarına keçileriyle birlikte yerleştirilmişlerdir. Meydanda gerçekleşen bu çekişme, ileride yaşanacak olan "keçi tasfiyesi ve katliamının" ilk nüvelerini vermekle birlikte; Çanga'nın isyankâr ruhu, keçi kılından kaftanı ve Tito'nun serpuşuna benzer başlığı ile beyaz karşı-devrimin liderine dönüşeceğinin önsezisidir. Çobanlar, zaman içinde konutlarına keçileri için eklenmiş kulübeler inşa etmişlerdir. (Starova, $2000 b$, s. 20) Burada aşırı yoruma giderek, yazarın şehrin günümüzdeki görünümüne hâkim olan atmosfere, plansız yapılaşmanın doğurduğu çirkinliğe göndermede bulunduğunu ifade edebiliriz.

Kentin kıtlık ve açlıkla mücadele ettiği dönem boyunca keçilerin sütü, sütten yapılan peyniri handiyse herkese yeni bir hayat bahşetmiştir. Federasyondakiler 
dahi gönderilen keçi peynirinin ve sütünün müptelası hâline gelmiş, kısa süreliğine de olsa çobanlara ses çıkaramamışlardır. Kısa süreliğine diyoruz, çünkü keçiler iktidara göre yine de öldürmek ve tasfiye etmek için potansiyel sebeptir. Ancak bu durum kentlilerin keçilere bağımlı hâle geldiği gerçeğini değiştirmez. Kurgunun merkezine konumlandırılan göçmen aile başta olmak üzere, insanlar açlıkla baş etmenin yolunu çobanlardan keçi satın almakta bulmuşlardır. Savaşlar ve çatışmalar kan getirirken keçiler, sütüyle bembeyaz bir gelecek vaat eder. "Süt" ve "kan" Keçiler Dönemi'nin sinematografik imgeleridir.

"Neyse ki, kentte, tüm ayrılıklarla, bölünmelerle kirlenmiş kanın aksine, milliyetleri, mezhepleri, sosyal kökenleri ne olursa olsun, bütün insanları birbirine yaklaştıran beyaz ve cömert bir bolluk da -keçilerin sütü- akıyordu." (Starova, 2000b, s.23)

Keçi sütünün çarpıcı anlatımına bir de romanın sonlarına doğru, beklenen korku gelip çattığında (keçilerin ölüm emri), Çanga'nın tüm çobanların keçilerini kattığı sürüsüyle birlikte Şato'ya sığınıp -belki kurtuluruz umuduyla- ölümü beklediği anlarda tesadüf ediyoruz. Madem keçiler her hâlükârda ölecekler; o hâlde doğalarına uygun olarak, iç güdüleri gereği yarı karanlık bir ortamda, onlara layık şekilde ölsünlerdi... (Starova, 2000b, s. 147). Çobanların polis ve askerin sıkı denetime rağmen örgütlenerek Çanga ve keçilere hava kuyusundan gizlice yiyecekler fırlatmasına karşılık Çanga da aileleri kıtlıktaki yegâne gıda olan sütten mahrum bırakmamak için, keçilerin sütünü sağarak kurduğu boru düzeneğiyle toprağa aktarır ve topraktan bembeyaz süt fışkırmasını sağlar. Böylece çobanlar keçilerinin yokluğunda, topraktan fışkıran sütü kaplarına doldurup eleyerek temiz bir süt elde etmiş olurlar. Kan ve sütün birleşmesi gibi, toprak ve süt de birleşir. Bu, son derece sinematografik ve mistik bir sahnedir.

"Ve şimdi birdenbire keçi sütü akmaya başlamıştı.

Ölümün, boğazına sarıldığı anda bile Çanga, yüce Çanga hepimizi, mahallesindeki dostlarını, çocukları, anları, ihtiyarları düşünüyordu. İnsanlar topraktan fışkıran sütü kaplara doldurmak için hızla örgütlendiler." (Starova, 2000b, s. 152)

Starova'nın romanında sinematografik uzantılar taşıyan unsurlar yukarıda bahsedilenlerle sınırlı değildir. Çanga'nın gerçek adı Melko Melovski, Balkan sinemasının Angelopoulos'la birlikte en çok konuşulan yönetmeni Milcho Mančevski'yi anımsatır. İsim seçimi muhtemelen tesadüfî olmakla birlikte, Starova'nın anlattığı coğrafya ve sancıları Mančevski'nin Yağmurdan Önce (Pred Doždot, 1994) ve diğer filmleriyle karşılaştırmalı okunabilir. "Kelimeler", "Yüzler" ve "Resimler" bölümlerinden oluşan, birbirinden bağımsızmış gibi görünen kişilerin 
ve hikâyelerin yolunun kronotop unsuru sayesinde Makedonya'da kesiştiği film; yansıttığının aksine esasen eve dönmeyi değil, "eve dönememeyi" yahut "dönülen yerin artık eski ev olmayışını" anlatır. İç savaşın yol açtığı yıkımlar, birlikte yaşama zorunluluğuna rağmen gerilmeye her an müsait ırk/din çatışmaları (Hristiyan Makedonlar ile Müslüman Arnavutlar), komünizm sonrası Yugoslavya'nın ahvâli (tıngır mıngır ilerleyen eski kırmızı otobüsler, devriye gezen BM tankları, Cocacola ve Marlboro reklam afişleri...) görsel dilin sunduğu imkânlar ve müziğin de ambiyansa katkısıyla çarpıcı biçimde gözler önüne serilir. Roman ve film birbiri ardına okunup izlendiği takdirde; okur-izleyici muhayyilesinde mukayeseye, coğrafyayı daha iyi tanımaya ve zengin çağrışımlara olanak sağlar. "Göç" olgusu, "mültecilik" sorunu, savaşlar neticesinde insan eliyle çizilen "sınır" ve "sınır ötesi" mefhumlarına dair sorgulamalar; Angelopoulos'un Ulis'in Bakışı (To Vlemma tou Odyssea, 1995) ve Leyleğin Geciken Adımı (To Meteoro Vima Tou Pelargou, 1991) filmlerinde de tabiat unsurları ön plana çıkarılarak -"su/nehir", "kar" vb. şiirsel biçimde ortaya koyulur.

Edebiyatın resim sanatıyla olduğu kadar 20. yüzyıldan itibaren sinemayla da yakın ilişki kurduğunu görürüz. Hatta kimi eleştirmenler, fotoğrafın -dolayısıyla sinemanın - icadının resim sanatının sonunu getirdiği görüşünde birleşmiştir. Günümüzde edebiyatın sinema ile olan bağı ağırlıklı olarak iki yolu izler: 1 . Göstergelerarasılık/metinlerarasılık bağlamında edebiyat ve sinemanın birbirini beslemesi. 2. Edebî metinlerin sinemaya uyarlanması. Çalışmamızın üçüncü bölümünde inceleyeceğimiz metinlerarası ilişkileri bolca kullanan yazarın Keçiler Dönemi romanı, barındırdığı görsel imgelerle hem sinematografiye uygun olması hem de Balkan sinemasının izleklerini roman türünde yansıtması bakımından sinemayla ilişkilendirilebilir.

\section{Arketipçi Eleştiri (Archetypal Criticism) Bağlamında 'Nehir/Su' İmgesi ile 'Göç' İzleği Arasındaki îlişki}

Arketip Jung'a göre; kökensel bir imgeyi belirleyen ve bilinçaltında bulunan bir terimdir, bir kompleks biçimidir ama kişisel deneyimin meyvesi değildir. Doğuştan bir komplekstir, enerji dolu bir merkezdir. (Jung, 2001, s. 230-231) "Arketip Kavramı Üzerine" tartışırken "daha antikçağda bile kullanılan ve Platon'un 'idea'sıyla eş anlamlı bir kavram" olduğunu ifade eder (Jung, 2017, s. 17) ve "arketiplerin içerik olarak değil, yalnızca biçimsel olarak belirlenmiş olduğunu, biçimsel belirlenmelerinin de son derece kısıtlı olduğunu" vurgular. (Jung, 2017, s. 21)

Göç, romanın temel izleklerindendir. İnsanlar üzerindeki trajik boyutu benzerlik gösterse de "iç göç" ve "dış göç" olmak üzere, eserde iki farklı şekilde kar- 
şımıza çıkar. Kurgunun omurgasında yer alan ve üyelerinden hiçbirinin adı zikredilmemiş aile (anne, baba, çocuklar ve sonradan aileye katılan -Blanchette, Stalinette ${ }^{4}$ ve Laideronne adındaki-üç keçi) "gölün batı yakasındaki kenti terk ederek" büyük göç ile Üsküp'e gelmiştir. Yazar burada özkurgu (autofiction) yapıyor. Zira Starova'nın kendisi de Arnavutluk'ta, Ohri Gölü’nün güney yakasındaki Pogradec'te doğmuş; sonradan Kuzey Makedonya'nın başkenti Üsküp'e göç etmiştir. Bahsettiğimiz çakışımı inandırıcılık bakımından, "saf okur" yanımızla belki daha sansasyonel bulmamıza karşın; şunu da unutmamak gerekir ki "kurmaca"nın gerçeği "kurgulamadan", birebir yansıtması mümkün değildir.

Öte yandan; maddi yurtsuzluk ve sürgünlük zeminine oturtularak somutlamaya gidilmiş varoluşsal sancıların, kıvılıımını bu "köksüzlük"ten devşirdiği inkâr edilemez. Romana dönersek, ailenin yukarıda zikredilen hikâyesi dış göçe örnektir ve iç göç ile dağlardan kente inmiş çobanlara nazaran birey üzerindeki etkisinin, zorluklarının daha büyük olduğu vurgulanmıştır. Nitekim ana vatanının sınırını geçtikten sonra "yurtsuz" sayılan göçmen ailenin, yeni ülkede "yurttaş" kabul edilebilmesi için belli bir zamanın üstesinden gelmesi gerekmiştir. Ailenin üyeleri, bahsettiğimiz süre zarfında gerçekleşebilecek tüm aksiliklerde, iç göçmenlerden önce kendi hayatlarının tehlikeye girmesi korkusuyla baş başa kalmıştır. Nehir/su imgesi ile göçmenlik arasında bağ kurulması "arketipçi eleştiri (archetypal criticism)"ye kapı aralamıştır.

"Hızla akan nehrin kıyısında yaşamak her an gitmeye hazırmışı gibi bir izlenim uyandırıyordu. (...) Nehir, varlığımızı atalarımızın beşiğine bağlayan kökleri çoktan koparmış olan bizler için, başka yerlere sürekli bir çağrı, denizlerin ötesinde bilinmedik ülkelere göçmeyi sürdürmemize bir davet oluşturuyordu." (Starova, 2000b, s. 27)

Eserde girift şekilde işlenen "ölüm", "arama/arayış", "yolculuk" ve "yeniden doğuş" arketiplerinin izleri de rahatlıkla sürülebilir. Göçülen topraklar zamanla eriyen ya da eriyip gittiği sanılan geçmiş ise; bilinmedik ülkelerin çağrısını terennüm eden nehir, yeniden doğuşun maddi ve manevi simgesidir. "Su, arındırır ve yeniler; çünkü 'geçmişi' siler, ilk baştaki bütünlüğü -yalnızca bir an için de olsayeniden kurgular." (Eliade, 2003, s. 202) Bachelard Su ve Düşler' de suyun tözünde, yüzeysel imgeleri altında ateşin ya da taşın derinliklerinden çıkan özden çok farklı bir öz ve sürekli bir doğuş bulunduğunu açığa çıkarmaya çalışır: "(...) Okur sonunda suyun da bir yazgı türü olduğunu, yalnızca kaçıp giden imgelerin boş yazgısı, bitmeyen bir düşün boş yazgısı değil, varlığın tözünü durmaksızın dönüştüren temel bir yazgı olduğunu anlayacaktır." (Bachelard, 2006, s. 12) Romanda

\footnotetext{
${ }^{4}$ Stalinette'nin ismi keçi sayımında, nüfus görevlisinin Stalin'in adının küçük düşürülmemesi uyarısı üzerine Libérette olarak değiştiriliyor.
} 
derin yapıya gizlenen; suyun dönüştürücü, sağaltıcı, dişil niteliği coğrafyanın ve siyasi anlaşmazlıkların yüzey yapıdaki realitesiyle harmanlanarak daimî "gitmek yazgısı"na tahavvül eder. Keçiler Dönemi'nde nehir (Vardar), Bachelard'ın denemelerinde maddesel imgelem izlekleri doğrultusunda dikkat çektiği hemen bütün uzantıları taşır. Adeta bir karaktere, varlığa, ruha, kuşatıcı ve kurtarıcı bir bedene sahip hâle gelir. Fiziksel ve ruhsal anlamda bireyleri baskılayan dar bir mekâna sıkışıp kalmayı değil, uzaklara göç etme ihtimalini muştular. Starova'nın suyun zengin imgesel gücünden faydalanmaktaki başarısının ardında, biraz da şair yönü (Kartaca Şiirleri) yatmaktadır.

Romandaki anlatıcı, bahsettiğimiz göçmen ailenin çocuklarından biridir ve ağırlıklı olarak "birinci çoğul şahıs/biz" dilini kullanmıştır. Yani yazar, anlatıcılık görevini roman kişilerinden birine vermiştir. Fakat şunu da belirtmekte yarar var: Yer yer çocuk bilincine, saflığına dair izlenimlere kapılsak da anlatıcıdan farklı olarak, bakış açısı çocuk bilinciyle sınırlı kalmamıştır. Kurgudaki isimsiz kişilerin iç benliğine, zihnindeki düşüncelere, hâl ve hareketlerinin sebep ve sonuçlarına hâkim olunmasından; olayların, tarihî ve siyasi arka planına dair değerlendirmelerden ve ayrıntılı tasvirlerden yola çıkarak "kahraman anlatıcının bakış açısı" dışında, "tanrısal" ve yer yer de "gözlemci bakış açısı"nın kullanıldığını söyleyebiliriz. Esasen yazar, camera obscura misali mercek altına aldığı kişilere ve olaylara göre, zamanda geriye dönüş ve ileri gidişlerle kullandığı bakış açısını da değiştirmiştir.

\section{Keçiler Dönemi’nde Metinlerarasılık (Intertextuality): Balkan Don Kişot'u Olarak Baba Figürünün Entelektüel Portresi}

Romanda metinlerarasılık tekniğinin nasıl kullanıldığına dair tespitlere geçmeden evvel metinlerarası ilişkiler hususunda kafa yoran kuramcıların görüşlerine yer vermek yerinde olacaktır:

"Jean Claude Vareille'nin 'kitap dönemi sona erdi; yazı dönemi özellikle de dillerin ve alıntıların söyleşisi başladı' olarak ifade ettiği metinlerarasılık, Roland Barthes'e göre 'sonsuz bir metin dışında yaşamanın olanaksızlığı'; Julia Kristeva'ya göre 'başka metinlerden alınan sözcelerin kesişme yeri'; Mihail Bakthin'e göre söyleşimcilik kuramı çerçevesinde 'etkileşim'; lori Lotman'a göre 'metin-dışı ya da metin-ötesi bağıntılar; Michael Riffaterre'a göre 'okurun kendinden önce ya da sonra gelen bir yapıtta başka yapıtlar arasındaki ilişkileri algılaması'; Laurent Jenny'e göre 'çok sayıda metnin, anlamın başını çeken bir ana metin ile dönüştürülmesi ve benzeştirilmesi işi'; Gerard Genette'a göre 'bir metni açık ya da kapalı bir biçimde öteki metinlerle ilişki içerisine sokmak' ve Jean BelleminNoel'a göre ise 'yazının kaynağını adsız bir belirsizlik içinde eriten avant-texte (metin öncesi)'dir." (Eliuz, 2016, s. 122) 
Görüldüğü üzere, kuramcılar metinlerarasılığın tanımı ve sınırları konusunda görüş birliği içinde değildir. Bilhassa Bakhtin, Barthes ve Saussure Kristeva'nın metinlerarasılığı terimleştirmesine giden yolların taşlarını döşemiştir. Kristeva âdeta her metni bir mozaik, okuma etkisi olarak görür; metinlerarasılığa dar bir çerçeveden değil oldukça geniş bir perspektiften bakar. Diğer çalışmalarımızda da değindiğimiz gibi, metinlerarasılıktan söz edilebilmesi için ana metinle "konu", "üslup" ve "biçim" ilişkisi kurulması gerektiği görüşündeyiz. Bazı araştırmacılar tarafından "taklitten ibaret" görülmekle olumsuz eleştiriler alan bu terkip; esasında farklı türleri ve sanat görüşlerini kendi içinde bağ kuracak şekilde inşa etme yetisi, muhayyile gücüyle onlara yeni bir form ve anlam verme becerisi bakımından ayrı bir biçim estetiğini oluşturmaktadır. Yazarın "bilinçli" olarak uyguladığı ve çoğunlukla parodi maksadını güttüğü aslında "dilsel taklit"tir. Burada bilinçli ifadesinin altını özellikle çizmek gerekir. Aksi takdirde, sözgelimi Ahmet Mithat'ın ya da Yakup Kadri'nin eserleri de bu teknik bağlamında incelenmeye müsait hâle gelir. Oysa bahsi geçen her iki yazar da yaptığının "farkında değildir". Göndermeleri yapıya sinmediği için ancak anma boyutunda kalır. Konuya, üsluba, biçime sızmadığı sürece de her anma metinlerarasılık bağlamında değerlendirilmemelidir. Tıpkı çerçeve hikâye tekniğinin kullanıldığı her metnin üstkurmacayı barındırmaması gibi.

Keçiler Dönemi'nde, gönderge (référence) boyutunda metinlerarasılık (intertextuality) tekniğinden faydalanılmıştır. Kubilay Aktulum'un tanımına göre; açık metinlerarası biçimi olan 'gönderge', yapıtın başlığını ya da yazarının adını anmakla yetinir. Gönderge, bir metinden alıntı yapılmadan okuru doğrudan bir metne gönderir. (Aktulum, 2014, s. 82) Görsel sanatlara dair göndergeleri çalışmamızın ilerleyen kısmında ekphrasis bağlamında ele alacağımızdan dolayı, burada yalnızca yazarın diyalog hâlinde olduğu diğer yazarlar ve eserlerinden bahsedeceğiz.

Gönderme yapmaya olanak sağlayan, "aydın-baba" figürünün zengin bir kütüphaneye sahip olması ve hayatını kitaplar -ansiklopediler, atlaslar, astronomi kitapları, zooloji ve botanik el kitapları, büyü kitapları... - arasında geçirmesi; Başkeçi Çobanı Çanga'ya okuma-yazma öğretmesi, teorik bilgilerini onunla paylaşması; buna karşıı Çanga'nın da babaya pratik yaşamdan edindiği tecrübelerini aktarması, böylece karşılıkı fikir münakaşalarında bulunmalarıdır. Babanın Çanga'ya verdiği kitaplar, Çanga yoluyla diğer çobanların eğitilmesine de katkı sağlamıştır. Çünkü Çanga eserleri, kendi yorumlarını da katarak sesli biçimde arkadaşlarına okumaktadır. Bu suretle, çobanları -“Sonumuz böyle olur mu?" düşüncesiyle- ürküten Alphonse Daudet'nin “Mösyö Seguin'in Keçisi" adlı öyküsü, adeta romanın kehanetine dönüşmüştür. Seguin'in keçisi Çanga ve keçileri gibi ölmek pahasına özgürlüğü seçmiştir. Ve kahramanca savaşsa da sonunda güçlüye 
(kurda) yenik düşmüş, acı yazgıdan kurtulamamıştır. Çanga ve çobanlar da bir gün mutlaka geleceğini bildikleri "keçilerin ölüm emri" korkusuna karşın kadere karşı çıkmaktan geri durmamıştır. Zira modern bir tür olan romanın tragedya ile hâlen göbek bağı vardır. Çanga'nın keçileriyle Seguin'in keçilerinin öyküsü paralel okunabilir.

Daudet'nin öyküsü dışında, Antik Latin şair Catullus'un ${ }^{5}$ "keçilerin özgürlük içinde dolaştıkları Roma forumunun gravürleriyle süslenmiş eseri" ne de göndermede bulunulmuştur. (Starova, 2000b, s. 62) Operada "Carmen" oynanırken keçilerden birinin sahneye çıktığı ânı opera yetkililerinin "rezalet" olarak addetmesi ve şikâyetlerinin Parti Sekreteri'ne kadar ulaşması, bu gravürün absurdeün sularında yüzen parodisidir. Baba figürü için "Balkan Don Kişot'u" ifadesinin kullanılması rastlantı değildir. (Starova, 2000b, s. 29) Kitaplar belli sınırlar içine sıkıştırılmış bu insanlar için arzuladıkları hâlde yaşayamadıkları başka hayatları yaşama, tanıyamadıkları dünyayı tanıma fırsatını sunar. Kitapların ülkelerin aksine, tıpkı kuşlar gibi sınırı yoktur.

Romanın başından sonuna dek çok defa rastladığımız ve leitmotiv tekniğinin yansıması olarak telakki edebileceğimiz "kitapların üzerine vuran sarı ışık"; bilge/aydın babanın portresini tamamlarken, kurguya bütünlük kazandıran bir ahenk katmaktadır. Bununla birlikte, yazarın cümle boyutuna varan bazı ifadeleri farklı bölümlerde birden fazla kez kullanması, zaman zaman tekrara düştüğünü gösteriyor. Yeri gelmişken söyleyelim: Üslûba halel getiren, romanı zedeleyen bir diğer durum; özellikle siyasi ve tarihî arka plan aktarılırken yazarın şiirsel dili bırakıp adeta makale dilinin makinemsi soğukluğunu kullanması, bilgiç edaya bürünmesidir. Bu tavır her ne kadar aydın/baba portresine uygun düşüyormuş gibi gözükse de derin yapıda "okuru eğitmek" hummasından kurtulamayan "sorumlu aydın yazar"ın uzantısıdır ve üslûbu, sanatsal kaygıyı sekteye uğratır. Halbuki Foucault, Barthes gibi kuramcılar yazarın ölümünü çoktan ilân etmiştir. Yazıda amaç, "tanrı-yazar"ın tamamen ortadan kalktığı (Dilin Çalışma Sesi'nde "kâğıttan yazar" ifadesi kullanılır) "sıfır derecesi"ne yaklaşmak, düzyazıyı kapalı bir doğa içine gizleyerek şiirselleştirmektir. (Barthes, 2016) Yapısalcılık ve post-yapısalclık kuramlarından sonra, yeni yazarın mottosu "anlatmak/bildirmek/öğretmek" değil; "göstermek/sezdirmek/hissettirmek"tir.

Baba figürünün kitaplarının bunca yer tutması ve ısrarla vurgulanması, aynı zamanda yazarın bir başka eseri Babamın Kitapları (Starova, 2000a) ile bu romanının birleşimini sağlayan unsurdur. Dahası, yazarın kendi eserlerine dönük

\footnotetext{
${ }^{5}$ Gaius Valerius Catullus (d. MÖ 84; ö. MÖ 54), 14. yüzyılda Verona'da el yazması bulunana kadar pek de bilinmeyen Romalı şairdir. Hayatı hakkındaki kısıtlı bilgiler şiirleri dışında; Jerome, Apuleius ve Suetonius' dan öğrenilebilmiştir. bk. (Poetry Foundation, 2020).
} 
göndergeleri bununla sınırlı değildir. Babanın bilincini temaşa ederken; evlatlarının Balkanlar'daki geleceğini düşündüğünde, "tanrıtanımazlık müzeleri"nin kurulması fikrini korkunç bulduğunu öğreniriz. Bu tasa, Keçiler Dönemi'ni Babamın Kitapları ile üçlemenin diğer romanı Tanrıtanımazlık Müzesi'ne (Starova, 2007) bağlar.

Starova'nın diğer eserlerinden söz açılmışken; romanlarının tarihî arka planına ve kaynağına dikkat çekmek adına, bir röportajında Kül Kalesi'nin yaşanmış gerçekliğe yakınlık itibariyle ne ölçüde kurmaca ne ölçüde tarihî roman sayılabileceği hususundaki soruya verdiği ayrıntılı cevabı zikretmek faydalı olacaktır:

"Kül Kalesi romanı, tarih sürecinde insan varlığının mutlak tecrübesi peşindedir. Bu roman bana ait romanları içeren büyük projemin bir parçasıdır. Bu projenin on romanı Arnavutça ve Makedonca olmak üzere çıkmış durumdadır. Bu on romanın dördü Yapı Kredi Yayınları tarafından Türkiye'de Babamın Kitapları, Keçiler Dönemi, Kül Kalesi, Tanrıtanımazlık Müzesi başılıları altında basıldı. Roman tarzı projemin genel ismi "Balkan Destanı"dır. Balkan Destanı projem Türkiye'de olduğu gibi Amerika, Fransa, Almanya, Italya ve diğer dünya devletleri ve dillerine açık olan bir projedir; bütün bu devlet ve dillerde yayınlanmış durumdadır. Biz Balkanlılar için Churcill'in söylediği gibi; "Balkanlılar kullandığından fazla tarih oluşturmaktadırlar." Bendeniz yazar olarak Müslüman bir Arnavut ailesinin 20. yüzyılının son geçen yüz yılını konu edinmeye çalışıyorum. Bu romanlar destanımın yüz yılın ellisi, yazarın babası ve ailesine aittir, diğer yarısı ise yazarın kendi hayat tarihçesini içermektedir. Bunların kaynağı babama ait tevârüs ettiğim canlı ve mistik kütüphanedir. Bunlar kaybolan Balkan zamanını içermektedir, aynı şekilde 16.-19. yüzyıla ait sicillerin keşif sırrını da gizlemektedir. Roman bir ailenin hayat gerçekleriyle uğraşmaktadır, kaynak olarak hem canlı hâtıralar hem de tarihsel gerçeklerdir ki bunlar hatıraların hayal mahsulü olmamasını önlemektedir, gerçekler çerçevesinde kalmasını sağlamaktadır. Roman mı tarihsel roman özelliği mi ağır basıyor konusuna gelince burada tarihi hakikatleri içeren tarihsel roman özelliği ağır basmaktadır." (“Ata'nın Gizemli Hayatı", 2008)

Jale Parla'nın Tanzimat romanı için kullandığı "babalar ve oğullar" metaforu (Parla, 2014); Keçiler Dönemi'ne de rahatlıkla uyarlanabilir, tek bir farkla: Tanzimat romanında baba ölmüş, oğul babanın görevini üstlenerek toplumun sorumluluğunu almıştır. İncelediğimiz romanda baba hayattadır ve ailenin babası olduğu kadar köylü halkın (çobanların) da babasıdır. Çünkü Çanga başta olmak üzere diğer çobanlara "öz ben"ini buldurmuş, onları gerçeklere uyandırmıştır. Lâkin baba gücünü "eylemsizliği" nden almaktadır. Gerçek yaşantıdan kopuktur. Çanga ise soylu vahşî tabiatıyla, kahramansı özellikleriyle babanın cesaret edemediğini yapmış; ölüme yürümek pahasına keçileri teslim etmemiştir. Çanga esasen 
kahramansı şekilde tasvir edilmesinden ve Stalinleşmesinden de anlayacağımız üzere - "Tıpkı 'Yaşasın Tito-Stalin' der gibi, herkes 'Yaşasın Tito-Çanga' diyordu." (Starova, 2000b, s. 111)- direngenliğiyle babayı yıkmış ve onun yerine geçmiştir. Illk bölümlerde ailelerin oturma odasında zorunlu olarak Tito ve Stalin'in fotoğrafı varken, ikili arasındaki siyasi kopuştan sonra ${ }^{6}$ Stalin'in portresi çekmecelere kaldırılmış; beyaz-karşı devrimin önderi, Keçiler Prensi Çanga'nın fotoğrafı bir zorunluluğa tâbi olmaksızın "içten gelerek" aile fotoğraflarının yanında yerini almıştır. Babanın romanda eylemsizliğini bozduğu ve ailesini dizginlemekten vazgeçtiği tek an, Çanga'nın Yugoslav Cumhuriyetleri'ni incelemek üzere yaptığı geziden/ yolculuktan döndüğü gün meydandaki kutlamaya katılmasıdır.

Çanga, Joseph Campbell'ın Kahramanın Sonsuz Yolculuğu'nda (2013) etraflıca ortaya koyduğu gibi; "yola çıkış", "erginlenme" ve "dönüş" merhalelerinden geçmiş, keçiler ve bezgin halk için "kurtarıı" (kurduğu düzenekle keçilerin sütünü halka ulaştırması ve halkı açlıktan kurtarması) ve "savaşçı" (parti ideologlarına kafa tutması ve keçilerle karşı-devrime kalkışması) rollerini üstlenmiştir. Melko Melovski'nin (nâm-ı diğer Çanga) yaşamak için olduğu kadar yaşatmak uğruna da uğraşması mühimdir. Ona kolektif bilinci aşılayan, gerçeklere uyandıran yine bilge/entelektüel konumundaki isimsiz babadır. Romanı, Çanga'nın "kendi olma yolculuğu/mücadelesi" olarak okumak da mümkündür. Aralarındaki ilişki yer yer Stephen Dedalus ile Leopold Bloom'u andırır.

Baba figürü üzerinde bu kadar durmamızın bir sebebi de annenin portresiyle nasıl tezat oluşturduğunu göstermektir. Anne doğu toplumlarına has eril konumlandırma ile "kadın kimliği"nden azade, entelektüel bakımından derinliksiz, hayata dair yegâne amacı yavrularını yaşamda tutmak ve ölen çocuklarının yerine yeni canlar doğurarak ölümün karşısına hayatı koymak olan, bireyselliği örselenmiş, toplumsal normlara hapsedilmiş şekilde tasvir edilmiştir. Baba gecelerini kitaplar arasında geçirirken anne odaya girdiğinde bir defa olsun kitap okumaz. Kitaba temas ettiği an en fazla eşinin kaldığı yeri işaretlemekle sınırıdır. Baba, varoluşunu entelektüel eylemler ve yazmayı hedeflediği Balkan imparatorluklarının çöküşü hakkındaki kitapla (Balkan Imparatorlukları Tarihi) tamamlarken anne toplum tarafından belirlenmiş cinsiyetçi kalıplar ekseninde tamamlar. Baba İstanbul Üniversitesi'nde okumuştur ve Osmanlı Türkçesi'nin sayılı uzmanlarındandır. Oysa annenin eğitim aldığına dair hiçbir emare yoktur. Bu toplumda kadın çocuk doğurmasıyla kazandığı annelik vasfı; keçi süt vermesi bakımından kutsaldır. Roman, "feminist eleştiri" bağlamında incelemeye müsaittir. Her şeye rağmen, annenin evlatları için yılmaksızın gösterdiği çaba fedakârlığın zarif ve trajik örneğidir: "Annem şaşmaz bir el çabukluğu ile eriştelere, yuvarlak ekmek-

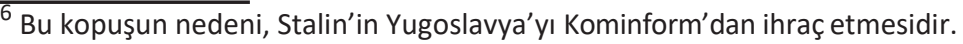


lere verdiği değişik şekiller sayesinde açlık bastırmak için kalan bir parça undan ekmek yoğuruyordu. Böylece, her gün farklı bir yemeğin tadını çıkarıyormuşuz gibi izlenime kapılmamızı sağlıyordu, oysa gerçekte, daima aynı hamurdu yediğimiz." (Starova, 2000b, s. 30)

\subsection{Metinlerarasılık/Göstergelerarasılık Bağlamında Chagall’in “Les amou- reux de Vence" Adlı Tablosunun Ekfrastik Tasviri}

Ekphrasis terimi çerçevesindeki tartışmaların tarihsel gelişimine baktığımızda, daha ziyade "şiir" ve "resim" sanatının mukayesesi yönünde ilerlediğini görürüz. Bazen düşman, bazen kardeş sanatlar olarak görülen şiir ve resmin göbek bağı yüzyıllardan beri devam etmektedir. (Anar, 2015) Platon'un “idealar kuramı” açısından, kopyanın kopyasını yansıtan ressamlar ve şairler tehlikelidir, ideal Devlet'ten uzaklaştırılmalıdır. Ancak Platon ve onun öğretilerini geliştirerek devam ettiren öğrencisi Aristo "mimesis-diegesis", "tragedya-komedya" gibi ayrımlar yapsa da Antik dönemde türler arası ayrıma bütünüyle gidilmiş değildir. Edebiyattan anlaşılan büyük oranda şiir sanatıdır. Modernist romanla birlikte ekphrasis yalnız şiirde değil, bir teknik olarak roman sanatında da kullanılmaya başlamıştır. Bilindiği gibi modernist roman, tıpkı şiir gibi daha seçkin bir okur kitlesine hitap eder ve bunu yaparken de sanatın tüm imkânlarını kullanır.

Ekphrasis tartışmalarına dönecek olursak; Anar ve Uzundemir'in değindiği üzere, bu analojinin ilk ciddî merhalesi Horatius'un "ut pictura poesis" ifadesiyle başladığı Ars Poetica (Şiir Sanatı) mektubudur. Da Vinci'nin Paragone'u, Mitchell'in Íkonoloji: Imaj, Metin, Ideoloji adlı eseri, Lessing'in Laocoön'u, müzelerin kurulması; resim-şiir mukayesesi bağlamında Batı edebiyatında ortaya çıkan ekphrasis tartışmalarının devamını oluşturur. Leonardo resmi şiire üstün tutarken, Lessing hareketi anlattığı için sözü imgeye üstün tutar. Ekphrasis teriminin teknik olarak önem kazanması 20. yüzyıla rastlar. Bunda göstergebilim ve metinlerarasılığın etkisi vardır. Foucault, Barthes, Derrida, Kristeva, Baudrillard, Rifaterre, Genette gibi kuramcıların çalışmaları; Picasso, Dali, Chagall vb. ressamların resim sanatındaki devrimleri sanata bakışa yeni bir ivme kazandırmıştır. (Anar, 2015) Kavram Antik Yunan'daki kullanımından farklı olarak günümüzde Heffernan ve Mitchell'in kabul ettiği üzere, "görsel bir sanat yapıtını sözle temsil etme" (Uzundemir, 2009, s. 231) anlamına gelmektedir. Ekphrasis, Aktulum'a göre; "okurun önüne yazından başka bir sanat biçimini (resim, heykel) çıkaran bir betimleme betisi; bir sanat yapıtını yazı aracılığıyla gösterme, sunma yolu"dur. (Aktulum, 2011, s. 26)

Romanın imgesel yoğunluğunu ve entelektüel altyapısını yansıtan, göstergelerarasılığın en çok hissedildiği kısım Chagall'in "Les amoureux de Vence" adlı 
tablosunun ekfrastik tasvirinin yapıldığı onuncu bölümün sonudur. Bu pasajda; tıpkı Chagall'in kompozisyonlarındaki gibi, "geçmiş-gelecek-hâl" iç içe geçmiş, çocuk-anlatıcı büyümüş ve yıllar sonra Paris'te, Chagall'in eseriyle karşılaşınca çocukluğun yitik cennetini yeniden bulmuştur. Bilindiği gibi sanat eserlerinin ânı dondurma, hapsetme ve yeniden diriltme özelliği vardır. Unuttuğumuzu ya da kaybettiğimizi sandığımız hâtıralar, bir şiirde ya da resimde ansızın beliriverir ve sonsuzluğa kavuşur. Hafızada yeni boyutlar kazanır. İşte resimdeki keçi de düşlerin sıkı ilmekleri ardına hıfzedilmiş geçmişin, belleğin lavını püskürterek ete kemiğe büründüğü "yergökyüzü" keçisidir.

"Yitik cenneti ölümsüzleştirebilecek bir imge, bir düşünce bulamadım onlarca yıl boyunca. Daha sonra, çok daha sonra, Paris'te bir Chagall sergisinde, köklerinden koparılmış ailemizin bağrındaki çocukluk cennetinin uçucu dönemi büyük bir tuvalin üzerinde karşıma çıkıverdi.

Chagall'in tuvallerinin sonsuz maviliklerinde, yeryüzüyle gökyüzünün birbirine karıştığı bu mavimsi gölgeler içinde, gökle yer arasında keçileriyle çevrelenmiş aileler fark ettim. Aslında, onları bir yere koymak imkânsızdı, çünkü yeryüzüne olduğu kadar gökyüzüne de aittiler." (Starova, 2000b, s. 72)

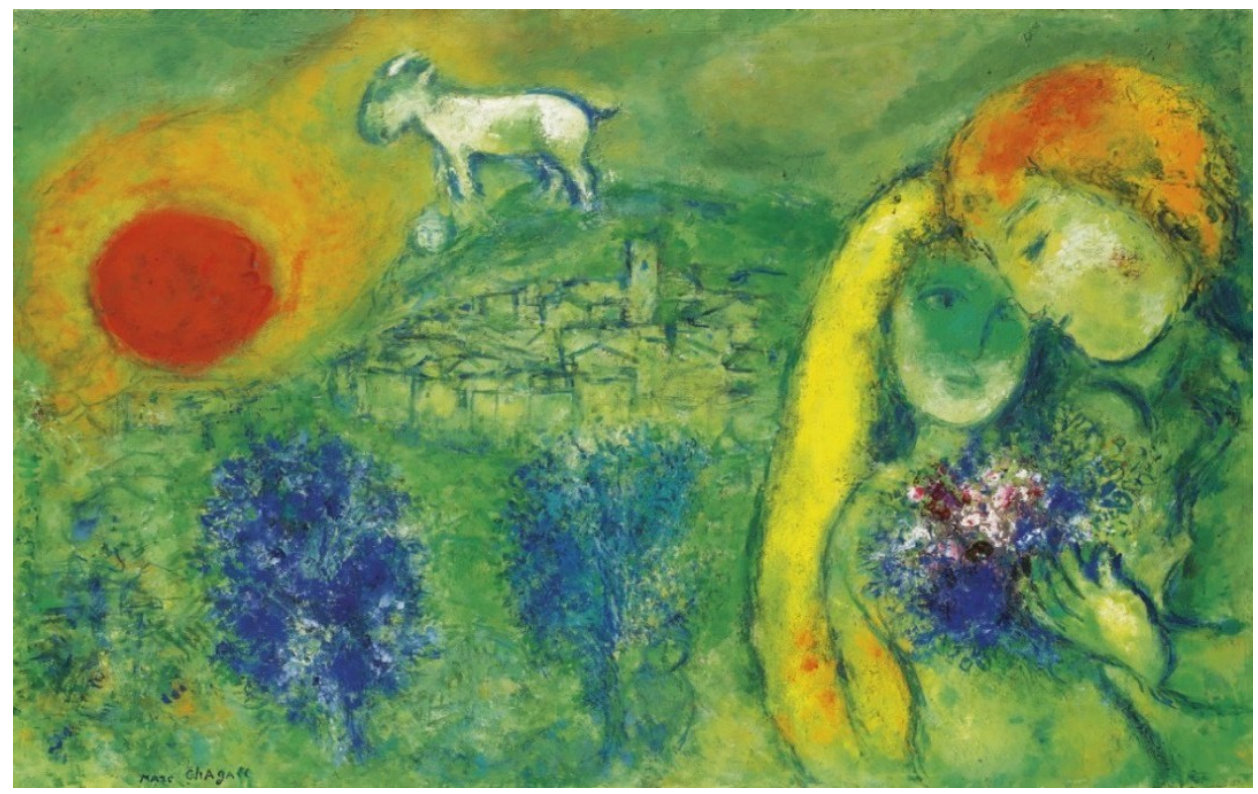

Şekil 2: Chagall'in tasvir edilen tablosu (Chagall, 1957). 


\section{Sonuç}

Çanga ve keçilere ne olduğu sorusu boşluğun sonsuzluğuna ve okurun muhayyilesine bırakılmıştır. Baba, kitapların dünyasından gerçek dünyaya dönmek suretiyle bir nevi kendi manevi intiharını yaratmış; Çanga keçileriyle birlikte sırra kadem basmış olsa da teslim olmamış ve maddi olarak ölse bile ki romanda öldügüne dair kesin bir iz yoktur - manevi anlamda ölümsüzlüğe kavuşmuştur.

Doğu'nun ve Batı́nın birbirini bütünüyle yok edemeden karıştığı Üsküp şehri eserde gerek mimarisi gerek barındırdığı renkler ile kayıp zamanın hafızasına ve labirent mekâna dönüşürken; Balkanlar’ın yüzyıllardır tanık olduğu göçler, savaşlar ve dini hedef alan reformlar varoluşsal bunalımları, kimlik sorununu (öteki ve azınlık vurgusu), bireyin zorunlu olarak siyasallaşmasını doğurmuştur. Kuzey Makedonya'da yaşayan Arnavut asıllı Starova; romanlarını Makedonca başta olmak üzere, Fransızca ve Arnavutça yazarak majör dilde edebî ürün vermektedir. Bu yönüyle Franz Kafka, Samuel Beckett ve bir düzeye kadar Sevim Burak gibi edebiyata minörün sesini getirmiştir. Makalenin birinci bölümünde, romanda açık (Üsküp şehri) ve kapalı mekân (konutlar ve kulübeler) unsurlarının ön planda olma sebepleri; ardında barındırdıkları tarih, iktidar ve kimlik çatışmaları, görsel imgeler doğrultusunda köklerinden kopma ve hiçbir yerin yerlisi olamama trajedilerine dayandırılarak irdelenmiştir. "Süt" ve "kan" yazarın betimleme yetisi ve temsil ettikleri manalar ile Keçiler Dönemi'nin sinematografik imgeleri olarak değerlendirilmiş; edebiyat-sinema bağı ekseninde romanla ortak izlekler yansıttığı tespitinden yola çıkarak Yağmurdan Önce, Ulis'in Bakışı ve Leyleğin Geciken Adımı filmlerine değinilmiştir. Bu saptamanın temelinde, eserdeki metinlerarası göndermelerin ve görsel unsurların yekûnu yatmaktadır.

Çalışmanın ikinci kısmında "nehir/su" imgesi ile "göç" izleği arasındaki ilişki "ölüm", "arayış", "yolculuk" ve "yeniden doğuş" arketiplerinin izlerinin sürülmesine; yakalanan damar roman kişileri ile yazarın biyografisi arasındaki kurgusal bağı, dolayısıyla eserdeki özkurgusal öğeleri saptamaya zemin hazırlamıştır.

İncelemenin üçüncü ve en geniş bölümü, metinlerin dünyasıyla örülmüş ilmekleri sökmeye yöneliktir. Borges öykülerinin evrenini anımsatır şekilde sonsuz bir kütüphane içine konumlandırılan "baba" figürünün entelektüel portresi, kıvılcımını babanın Kişotvari köklerinden devşiren çocuk-anlatııının Chagall tablosuyla kurduğu ekfrastik bağ ve Çanga'nın -yani modern zamanların destansı kahramanının- kendi olma yolculuğu romandaki metinlerarası ilişkilerin üst katmanını, çerçevesini oluşturur.

Yirmi iki bölüm ve "Sondeyiş"ten oluşan Keçiler Dönemi'nin anlamı hacmi- 
nin dışına taşan doğum-ölüm, faşizm-komünizm, aydın-halk, çoban-kentli, gazap-soğukkanlılık, öfke-iyilik, üzüntü-sevinç, güçü̈-zayıf, varlık-yokluk, süt-kan vb. çelişkileri ${ }^{7}$ nasıl bir romanla karşı karşıya olduğumuzun başlı başına göstergesidir. Bu yansımaların ayrıksı biçimde verilmeyip babanın, annenin ve Çanga'nın benliğinde birbiriyle savaşan mefhumlar olarak yerleştirilmesi mühimdir. Dünyadaki her şeyin zıttı ile var olması ve anlam kazanması misali, romanı roman yapan yazarın iç gerçeği ve hayatın dış gerçeği arasındaki uyumsuzluktur.

\section{Kaynakça}

\section{a) Starova'nın Bu Çalışma İ̧̧in İncelenen Eserleri}

Starova, L. (2000a). Babamın Kitapları. (Orhan Suda, Çev.). İstanbul: Yapı Kredi Yayınları.

Starova, L. (2000b). Keçiler Dönemi. (Orhan Suda, Çev.). İstanbul: Yapı Kredi Yayınları.

Starova, L. (2008). Kül Kalesi (Siciller). (Suat Engüllü, Çev.) İstanbul: Yapı Kredi Yayınları.

Starova, L. (2007). Tanrıtanımazlık Müzesi. (Orhan Suda, Çev.). İstanbul: Yapı Kredi Yayınları.

\section{b) Yararlanılan Diğer Kaynaklar}

Aktulum, K. (2011). Metinlerarasılık // Göstergelerarasılık. Ankara: Kanguru.

Aktulum, K. (2014). Metinlerarası iliş̧iler. Ankara: Kanguru.

Anar, T. (2015). Sonsuzluğun Yüzleri. İstanbul: Akıl Fikir.

Angelopoulos, T. (Yön.). (1991). Leyleğin Geciken Adımı (To Meteoro Vima Tou Pelargou) [Film]. Centre du cinéma grec-Arena Film-Vega Film-Theo Angelopoulos- Erre Produzioni (Yap.). Yunanistan.

Angelopoulos, T. (1995). Ulis'in Bakışı (To Vlemma tou Odyssea) [Film]. Phoebe Economopoulos-Eric Heuman-Giorgio Silvagni (Yap.). Yunanistan.

Bektaş, G. (2015). Üsküp’te Osmanlı Tiyatrosu. Mimar.ist: Dört Aylık Mi-

\footnotetext{
${ }^{7}$ Çatışma klasik gerçekçi roman için kullanmaya müsait bir terimdir. Modernist ve postmodern romanlarda çatışmadan ziyade çelişkiler, gelgitler vardır. Çünkü siyah bütünüyle siyah, beyaz bütünüyle beyaz değildir.
} 
marlık Kültür Dergisi, (54), 78-83.

Ata'nın Gizemli Hayatı (2008, 19 Eylül). Erişim adresi: https://www.hurriyet.com.tr/gundem/atanin-gizemli-hayati-9938706.

Bachelard, G. (2006). Su ve Düşler. (Olcay Kunal, Çev.). İstanbul: Yapı Kredi Yayınları.

Barthes, R. (2016). Yazının Sıfır Derecesi-Yeni Eleştirel Denemeler. (Tahsin Yücel, Çev.). İstanbul: Yapı Kredi Yayınları.

Campbell, J. (2013). Kahramanın Sonsuz Yolculuğu. (Sabri Gürses, Çev.). İstanbul: Kabalcı.

Chagall M. (1957). Les amoureux de Vence. (16 Şubat 2020) Erişim adresi: http://www.sothebys.com/en/auctions/ecatalogue/2015/impressionist-modern-art-evening-sale-I15006/lot.48.html

DARM: Kuzey Makedonya Cumhuriyeti Devlet Arşivleri (2020). Üsküp Departmanı, Üsküp, Kuzey Makedonya. (13 Şubat 2020,) Erişim adresi: https://commons.wikimedia.org/wiki/File:Panorama_od_Skopje,_stara_slika.tif

Daudet, A. (2000). Mösyö Seguin'in Keçisi. Değirmenimden Mektuplar I. (Sabri Esat Siyavuşgil, Çev.). İstanbul: Cumhuriyet-Dünya Klasikleri Dizisi: 116.

Demirci, N. (2009, 5 Mayıs). Balkanların romanında tarihin izini sürmek... Erişim adresi: https://www.bisav.org.tr/Bulten/35/595/ balkanlarin_romaninda_tarihin_izini_surmek.

Eliade, M. (2003). Dinler Tarihine Giriş. (Lale Arslan, Çev.). İstanbul: Kabalcı.

Eliuz, Ü. (2016). Oyunda Oyun Postmodern Roman. Istanbul: Kesit.

Gürel, Z. (2013, 5 Temmuz). Yitik zamana iz düşen roman... Erişim adresi: $\quad$ https://www.aydinlikgazete.com/images/dosyalarim/ kitapeki/2013/sayi71.pdf.

Ibrahimi, S. M. (April 9-11, 2018). The Place And Significance Of Ottoman Judicial Records In The Novels Of Luan Starova As Representative Of Macedoninan Literature. 1st International Congress on New Horizons in Education and Social Sciences (ICES 2018), 53-58. 
Jung, C. G. (2017). Dört Arketip. (Zehra Aksu Yılmazer, Çev.). İstanbul: Metis.

Jung, C. G. (2001). Insan Ruhuna Yöneliş. (Engin Büyükinal, Çev.). İstanbul: Say.

Karakuş, E., Uçkun, R. (2012). Balkan Halklarının Kimlik Belgeleri: "Kül Kalesi (Siciller)" Romanı Üzerine Bir Değerlendirme. Prof. Dr. Fikret Türkmen Kitabı. İzmir: Ege Üniversitesi.

Mančevski, M. (Yön.). (1994). Yağmurdan Önce (Pred Doždot) [Film]. Marc Baschet (Yap.). Ingiltere-Fransa-Makedonya.

MK Türk Tiyatrosu (2020). Millî Kurum Türk Tiyatrosu'nun Kuruluş Tarihçesi. (30 Kasım 2020) Erişim adresi: http:// www.turktiyatrosu.mk/tr/mll-kurum-trk-tyatrosunun-kurulu-tarhes.

Parla, J. (2014). Babalar ve Oğullar. İstanbul: illetişim.

Poetry Foundation (2020). Gaius Valerius Catullus. (16 Ocak 2020) Erişim adresi: https://www.poetryfoundation.org/poets/gaius-valerius-catullus

Uzundemir, Ö. (2009). Resim ve Edebiyat İlişkisinde Kadın İmgesi: Percy Bysshe Shelley'nin Şiirinde Medusa, Nazım Hikmet'te Jokond. Bilig, (51), 231-244. 